\title{
Primary Plasma Cell Leukaemia Case report and review of the literature
}

Sarika Singh, *Ashutosh Rath, Surekha Yadav

$$
\text { سرطان خلية بلازما الدم الأولية }
$$

$$
\text { ساريكا سينج، أشوتش راث، سوريكا ياداف }
$$

ABSTRACT: Plasma cell leukaemia (PCL) is one of the most aggressive and rarest forms of plasma cell dyscrasia. However, the diagnostic criteria for this condition have not yet been revised and there is no specific treatment to significantly improve the course of the disease. We report a 69-year-old male who presented to the Lok Nayak Hospital, New Delhi, India, in 2017 with dyspnoea and chest pain. A peripheral blood smear showed an absolute plasma cell count of $2.16 \times 10^{9} / \mathrm{L}$. A bone marrow examination showed $61 \%$ atypical plasma cells exhibiting kappa light chain restriction. Biochemical investigations were consistent with a diagnosis of primary PCL with renal involvement. Bortezomib-based chemotherapy was initiated, which resulted in an improvement in the patient's haematological and biochemical parameters. This case report includes a comprehensive review of the clinical and diagnostic features, pathobiology and treatment of PCL.

Keywords: Plasma Cell Leukemia; Multiple Myeloma; Plasma Cells; Case Report; India.

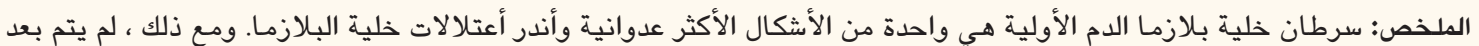

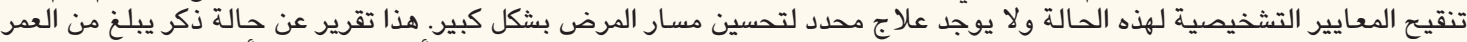

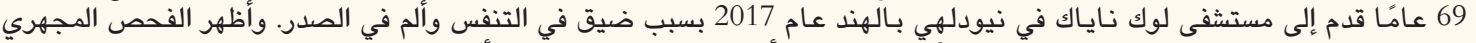

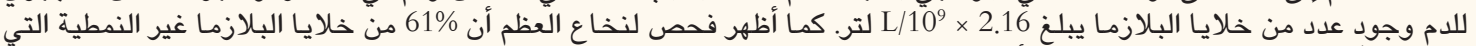

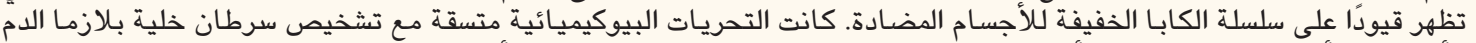

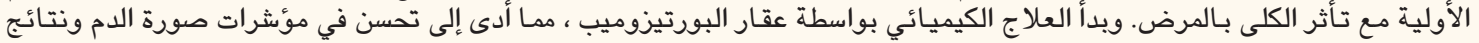

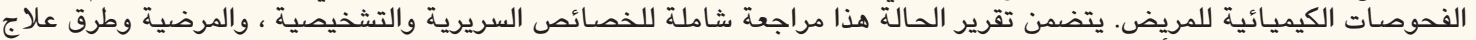
سرطان خلية بلازمـا الدم الأولية.

الكلمات المفتاحية: سرطان خلية بلازما الدم؛ المايلوما المتعددة؛ خلايا البلازما؛ تقرير حالة؛ الهند.

$\mathrm{P}$ ASMA CELL LEUKAEMIA (PCL) IS A RARE AND aggressive form of plasma cell dyscrasia. ${ }^{1}$ Primary PCL occurs de novo, whereas secondary PCL is the leukaemic transformation of relapsed or refractory multiple myeloma (MM). The incidence of PCL is $2-4 \%$, of which $60-70 \%$ of cases are primary and $30-40 \%$ are secondary, although the incidence of the latter type is rising. ${ }^{2,3}$ The median age of patients with primary PCL is younger than those with secondary PCL (52-65 years old versus 65-70 years old). ${ }^{2}$ In a case series by Rajeswari et al., four out of 16 patients with PCL were under the age of 40 years, with the youngest being 25 years old. ${ }^{4}$ Although primary and secondary PCL are considered different clinical entities, both have a poor prognosis. The median survival rate ranges from 6.8-12.6 months without novel therapy, although this increases to over three years after autologous stem cell transplantation. ${ }^{1,5}$

\section{Case Report}

A 69-year-old male presented to a local hospital in New Delhi, India, in 2017 with a two-month history of rectal bleeding and dyspnoea during routine activities. Heart disease was suspected and the patient was managed accordingly, with minimal investigations. Despite transient improvement, he subsequently presented to the Lok Nayak Hospital, New Delhi, in 2017 with dyspnoea and chest pain. During a general physical examination, there was evidence of pallor without lymphadenopathy. A systemic examination was unremarkable with no evidence of hepatosplenomegaly.

A complete blood count revealed anaemia with a haemoglobin $(\mathrm{Hb})$ level of $72 \mathrm{~g} / \mathrm{L}$, mild leukocytosis with a total leukocyte count (TLC) of $12 \times 10^{\%} / \mathrm{L}$ and thrombocytopaenia with a platelet count of $97 \times 10^{9} / \mathrm{L}$. The erythrocyte sedimentation rate was $70 \mathrm{~mm} /$ hour. A peripheral 


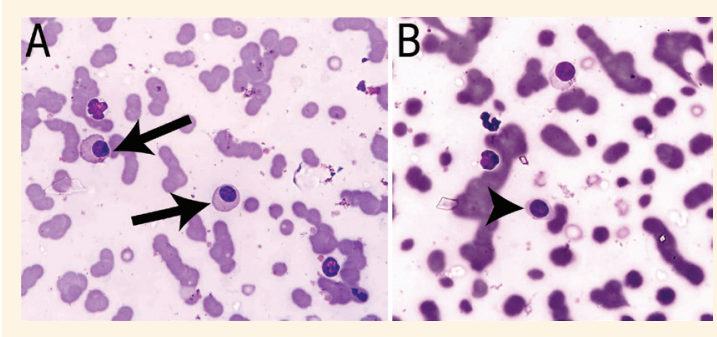

Figure 1: Peripheral blood smears at x200 magnification showing (A) rouleaux formation, plasma cells (arrows) and (B) atypical lymphocytes (arrowhead).

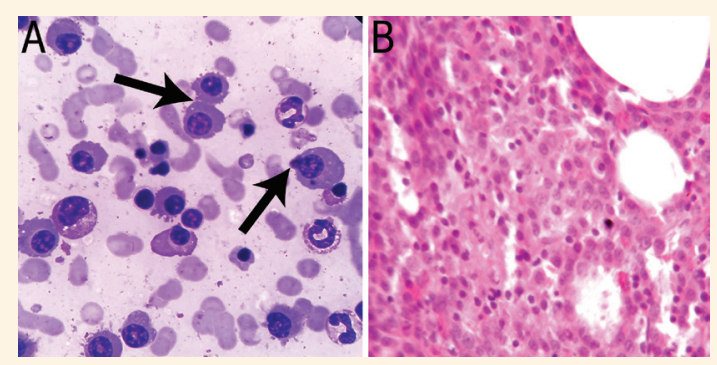

Figure 2: A: Bone marrow aspirate smear at x1,000 magnification showing atypical plasma cells (arrows). B: Haematoxylin and eosin stain at x400 magnification showing plasma cells.

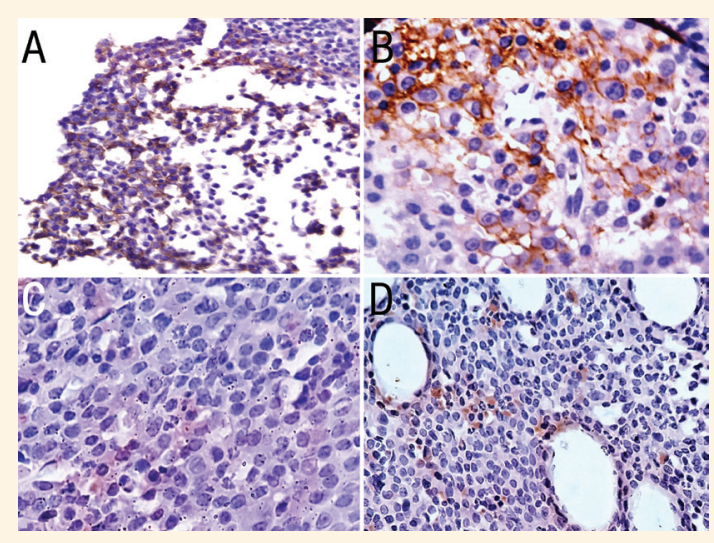

Figure 3: Immunohistochemistry panel at x400 magnification showing (A) positivity for cluster of differentiation (CD)38, (B) kappa light chain restriction, (C) reduced lambda light chain expression and (D) focal positivity for CD20.

blood smear exhibited normocytic/normochromic to microcytic/hypochromic red blood cells with extensive rouleaux formation. A differential leukocyte count revealed $18 \%$ plasma cells with an absolute platelet cell count of $2.16 \times 10^{9} / \mathrm{L}$ and $15 \%$ atypical lymphocytes [Figure 1]. Mature plasma cells as well as plasma cells with bipolar cytoplasm were present. The atypical lymphocytes had central and eccentrically placed nuclei and a moderate amount of cytoplasm with fuzzy cytoplasmic borders.

A bone marrow examination was performed to establish the extent of PCL involvement. A bone marrow aspirate smear and haematoxylin and eosin stain showed
$61 \%$ atypical plasma cells [Figure 2]. The morphological spectrum of these cells included thesaurocytes, plasma cells with bipolar cytoplasm and one to two prominent nucleoli in the nucleus and binucleated plasma cells. The bone marrow was hypercellular for age and showed the near-total replacement of the marrow spaces by the plasma cells, with focal areas of haematopoietic cells. Upon immunohistochemical analysis, the plasma cells were immunoreactive for cluster of differentiation (CD)38, showed kappa light chain restriction and reduced lambda light chain expression and demonstrated focal positivity for CD20 [Figure 3]. The cells were immunonegative for CD19 and p53.

Biochemical investigations showed high levels of serum creatinine ( $3.3 \mathrm{mg} / \mathrm{dL}$; normal range: $0.6-1.2 \mathrm{mg} / \mathrm{dL}$ ), blood urea (147 mg/dL; normal range: $8-23 \mathrm{mg} / \mathrm{dL}$ ) and serum uric acid (13.0 mg/dL; normal range: $4-8.5 \mathrm{mg} / \mathrm{dL}$ ). However, serum calcium levels were slightly low (8.5 mg/dL; normal range: 9.2-11 mg/dL). Radiological investigations, including a chest X-ray, abdominal ultrasound and skeletal survey, did not show any lesions. Serum protein electrophoresis indicated a total protein level of $15.20 \mathrm{~g} / \mathrm{dL}$ (normal range: $6.40-8.10 \mathrm{~g} / \mathrm{dL}$ ), albumin level of $3.83 \mathrm{~g} / \mathrm{dL}$ (normal range: 3.50-5.64 g/dL), $\alpha 1$ globulin level of $0.62 \mathrm{~g} / \mathrm{dL}$ (normal range: $0.17-0.41 \mathrm{~g} / \mathrm{dL}$ ),

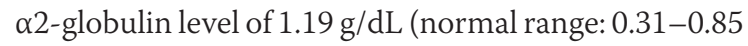
$\mathrm{g} / \mathrm{dL}$ ), $\beta$-globulin level of $0.59 \mathrm{~g} / \mathrm{dL}$ (normal range: $0.49-1.32 \mathrm{~g} / \mathrm{dL}$ ), $\gamma$-globulin level of $8.97 \mathrm{~g} / \mathrm{dL}$ (normal range: $0.62-1.53 \mathrm{~g} / \mathrm{dL}$ ) and albumin/globulin ratio of 0.34 (normal ratio: 0.90-2.00). Furthermore, the $\gamma$-globulin region showed a monoclonal spike. The raised globulins were found to be immunoglobulin (Ig)D on serum immunofixation electrophoresis. Bence Jones proteins were absent in the urine. A serum free light chain assay revealed kappa light chain restriction with elevated kappa free light chains at $204.00 \mathrm{mg} / \mathrm{L}$ (normal range: $3.30-19.40 \mathrm{mg} / \mathrm{L}$ ) and a kappa/lambda ratio of 27.72 (normal ratio: 0.26-1.65). Serum $\beta 2$-microglobulins were markedly raised at $15,576 \mathrm{ng} / \mathrm{mL}$ (normal range: 609-2,366 ng/mL).

Following confirmation of the diagnosis of primary PCL, the patient decided to undergo treatment at an oncology centre, at which point bortezomib-based chemotherapy was initiated. However, a follow-up haematological profile was performed at the Lok Nayak Hospital. After the first cycle of chemotherapy, the patient's TLC was $8.72 \times 10^{9} / \mathrm{L}$, Hb level was $106 \mathrm{~g} / \mathrm{L}$, platelet count was $157 \times 10^{9} / \mathrm{L}$, serum creatinine level was $1.4 \mathrm{mg} / \mathrm{dL}$ and blood urea level was $27 \mathrm{mg} / \mathrm{dL}$. On day 11 of the first cycle, a peripheral blood smear did not show any plasma cells. At the time of writing, the patient was stable; however, a follow-up bone marrow examination had not yet been performed to assess his remission status. 


\section{Discussion}

Myeloma cells are dependent for their survival on interactions with the bone marrow microenvironment. ${ }^{6}$ Myeloma cells require CD56-a neuronal cell adhesion molecule-to anchor to the bone marrow stroma. As CD56 expression decreases, myeloma cells gain access to the peripheral blood due to loss of contact with the bone marrow stroma. Patients with PCL therefore usually show decreased expression of CD56.7 Other molecules, such as CD27, CD117 and human leukocyte antigen-DR isotype, are usually negative, whereas CD19, CD20 and CD23 are often positive. In addition, cases of secondary PCL often show CD28 positivity. ${ }^{5}$ Interleukin- 6 is considered an important cytokine for PCL proliferation. ${ }^{8}$

In most primary PCL cases, genetic aberrancies are already present at the time of diagnosis; in contrast, the gradual accumulation of various genetic mutations make MM more aggressive, resulting in secondary PCL. ${ }^{1}$ Hypodiploidy or diploidy are present in $80 \%$ of PCL cases and are considered poor prognostic factors compared to hyperdiploidy, a common feature of MM. ${ }^{9}$ Both forms of PCL commonly show IgH translocations, notably in chromosome 14q32. Furthermore, amplifications of chromosome 1q21, MYC abnormalities and Ras mutations are more frequently seen in PCL than MM. ${ }^{10}$ In addition, 11q13 (cyclin D1) translocations are almost exclusive to primary PCL. ${ }^{1}$ However, Tp53 inactivation has been observed in both forms of PCL. ${ }^{2}$ It has been suggested that a phosphatase and tensin homolog deletion is responsible for the transition of MM to PCL. ${ }^{5}$

Due to extensive infiltration of the bone marrow by atypical plasma cells, the most common symptoms of PCL are related to severe anaemia and thrombocytopaenia, notably dyspnoea and haemorrhagic diathesis. ${ }^{1}$
Patients may also present with other clinical features, such as organomegaly, lymphadenopathy, pleural effusion and central nervous system involvement leading to neurological deficits and extramedullary plasmacytomas. In the current case, the patient initially presented with bleeding from the rectum and dyspnoea. Renal involvement can also occur, presenting as acute kidney failure, with studies indicating this is more commonly associated with PCL than MM (53-62\% versus $22-43 \%){ }^{11,12}$ A renal biopsy may show interstitial plasma cell infiltration, tubular casts and light chain restriction with direct immunofluorescence. ${ }^{13}$ The current case also showed renal involvement with raised blood urea and serum creatinine levels which normalised after chemotherapy.

Certain parameters can help to differentiate PCL from MM, including leukocytosis, relatively high levels of serum lactate dehydrogenase and $\beta 2$-microglobulins and lower frequencies of lytic bone lesions. ${ }^{1}$ In addition, patients with PCL usually only secrete free light chains, unlike those with MM. Moreover, plasma cells in PCL cases often show varying morphologies, ranging from classic plasma cells, plasmablasts and hairy-cell-like morphology to marked anaplastic features. ${ }^{4,14}$ In the current case, $15 \%$ of the lymphocytes were atypical in that their morphology differed from that of either classic or atypical plasma cells; instead, the cells resembled mature lymphocytes with fuzzy cytoplasmic borders. Previous case reports have documented similar lymphocyte-like morphologies in PCL cases. ${ }^{15-17}$ Although flow cytometry can help establish the actual nature of such cells, this could not be performed in the current case as the patient had been referred to an external oncology centre.

The diagnostic criteria for PCL were initially laid down by Noel et al. in 1974 and include the presence of $>20 \%$ of plasma cells ascertained to be clonal in nature in the peripheral blood or an absolute plasma cell count of $>2 \times 10^{9} / \mathrm{L} .{ }^{18,19}$ However, the presence of plasma cells

Table 1: Remission criteria per category for plasma cell leukaemia cases ${ }^{5}$

\begin{tabular}{|c|c|c|c|c|c|}
\hline \multirow[t]{2}{*}{ Category } & \multicolumn{2}{|c|}{ Plasma cells } & \multicolumn{2}{|c|}{ M-protein levels } & \multirow{2}{*}{$\begin{array}{c}\text { Extramedullary } \\
\text { disease }\end{array}$} \\
\hline & Peripheral blood & Bone marrow & Serum & Urinary & \\
\hline $\begin{array}{l}\text { Stringent complete } \\
\text { remission }\end{array}$ & Absent & $\begin{array}{l}\text { Undetectable by } \\
\text { flow cytometry }\end{array}$ & Negative & Negative & Absent \\
\hline Partial response & $1-5 \%$ & $5-25 \%$ & $\begin{array}{l}\geq 50 \% \\
\text { reduction }\end{array}$ & $<200 \mathrm{mg} / 24$ hours & $\geq 50 \%$ reduction \\
\hline Progressive disease & $\begin{array}{l}>5 \% \text { absolute } \\
\text { increase }\end{array}$ & $\begin{array}{c}>25 \% \text { increase or } \\
\text { absolute increase } \\
\text { of } \geq 10 \%\end{array}$ & $>25 \%$ increase & $>25 \%$ increase & Definite increase \\
\hline Relapse & Reappearance & $>10 \%$ increase & Reappearance & Reappearance & Any disease \\
\hline
\end{tabular}


in peripheral blood can also be seen in other plasma cell dyscrasias and certain non-malignant conditions such as severe sepsis and infectious mononucleosis. ${ }^{20}$ It has therefore been suggested that the diagnostic criteria of PCL should be revised to $>5 \%$ plasma cells or an absolute plasma count of $>0.5 \times 10^{9} / \mathrm{L}$ so as to avoid underdiagnosis of the condition. ${ }^{5}$ However, although the flow cytometric evaluation of PCL and revision of the criteria for diagnosis is currently under consideration, there is no consensus yet as further prospective multicentre analyses are required.

In terms of treatment, the proteasome inhibitor bortezomib has shown a relatively good response in both primary and secondary PCL, resulting in some cases in complete remission. ${ }^{21}$ Bortezomib combined with dexamethasone and melphalan has also been documented to show a good response, whereas thalidomide and lenalidomide have only shown a transient partial response. ${ }^{5}$ Allogenic stem cell transplantation can be considered in patients under 50 years of age; however, the risk of transplantation-related mortality is increased. ${ }^{1,5}$ Nevertheless, high-dose chemotherapy followed by autologous stem cell transplantation improves survival, although mainly for patients with primary PCL. ${ }^{2}$

Seven categories of PCL remission have been proposed by the International Myeloma Working Group, based on the following four main parameters: (1) the plasma cell count in the peripheral blood; (2) the plasma cell count in the bone marrow; (3) serum and urinary M-protein levels; and (4) the assessment of extramedullary disease [Table 1]. In general, a patient is considered to be in complete remission if plasma cells are absent from the peripheral blood and there are $<5 \%$ of plasma cells in the bone marrow. However, relapse is denoted by a $>10 \%$ increase in bone marrow plasma cells with the reappearance of peripheral blood plasma cells and M-protein, along with evidence of extramedullary disease. ${ }^{5}$ Jelinek et al. also recommended the assessment of minimal residual disease-negative remission by multicolour flow cytometry or allele-specific oligonucleotide polymerase chain reaction. ${ }^{1}$

\section{Conclusion}

Various significant yet subtle parameters can be used to differentiate primary PCL from MM. As the survival rate is low, such information is necessary to ensure that PCL cases can be diagnosed early and appropriate treatment regimens initiated.

\section{ACKNOWLEDGEMENTS}

A poster of the preliminary version of this case report was presented at the $58^{\text {th }}$ Annual Conference of the Indian Society of Haematology \& Blood Transfusion, from 2-5
November 2017 in Guwahati, Assam, India. An abstract of this poster presentation was subsequently published in the Indian Journal of Haematology \& Blood Transfusion in November 2017, Volume 33, Issue S1, Pp. S101-2.

\section{References}

1. Jelinek T, Kryukov F, Rihova L, Hajek R. Plasma cell leukemia: From biology to treatment. Eur J Haematol 2015; 95:16-26. doi: 10.1111/ejh.12533.

2. Tiedemann RE, Gonzalez-Paz N, Kyle RA, Santana-Davila R, Price-Troska T, Van Wier SA, et al. Genetic aberrations and survival in plasma cell leukemia. Leukemia 2008; 22:1044-52. doi: 10.1038/leu.2008.4

3. Bladé J, Kyle RA. Nonsecretory myeloma, immunoglobulin D myeloma, and plasma cell leukemia. Hematol Oncol Clin North Am 1999; 13:1259-72. doi: 10.1016/S0889-8588(05)70125-8

4. Rajeswari G, Paul TR, Uppin MS, Uppin SG, Rao DR, Raju DD, et al. Plasma cell leukemia: A case series from south India with emphasis on rarer variants. Indian J Med Paediatr Oncol 2014; 35:211-14. doi: 10.4103/0971-5851.142037.

5. Fernández de Larrea C, Kyle RA, Durie BG, Ludwig H, Usmani S, Vesole DH, et al. Plasma cell leukemia: Consensus statement on diagnostic requirements, response criteria and treatment recommendations by the International Myeloma Working Group. Leukemia 2013; 27:780-91. doi: 10.1038/leu.2012.336.

6. Mitsiades CS, McMillin DW, Klippel S, Hideshima T, Chauhan D, Richardson PG, et al. The role of the bone marrow micro-environment in the pathophysiology of myeloma and its significance in the development of more effective therapies. Hematol Oncol Clin North Am 2007; 21:1007-34. doi: 10.1016/j.hoc.20 07.08.007.

7. Pellat-Deceunynck C, Barillé S, Jego G, Puthier D, Robillard N, Pineau D, et al. The absence of CD56 (NCAM) on malignant plasma cells is a hallmark of plasma cell leukemia and of a special subset of multiple myeloma. Leukemia 1998; 12:1977-82.

8. Zhang XG, Bataille R, Widjenes J, Klein B. Interleukin-6 dependence of advanced malignant plasma cell dyscrasias. Cancer 1992; 69:1373-6. doi: 10.1002/1097-0142(19920315)69:6<1373::AIDCNCR2820690612>3.0.CO;2-1.

9. García-Sanz R, Orfão A, González M, Tabernero MD, Bladé J, Moro MJ, et al. Primary plasma cell leukemia: Clinical, immunophenotypic, DNA ploidy, and cytogenetic characteristics. Blood 1999; 93:1032-7

10. Chiecchio L, Dagrada GP, Ibrahim AH, Dachs Cabanas E, Protheroe RK, Stockley DM, et al. Timing of acquisition of deletion 13 in plasma cell dyscrasias is dependent on genetic context. Haematologica 2009; 94:1708-13. doi: 10.3324/haematol.2009. 011064 .

11. Bernasconi C, Castelli G, Pagnucco G, Brusamolino E. Plasma cell leukemia: A report on 15 patients. Eur J Haematol Suppl 1989; 51:76-83.

12. Woodruff RK, Malpas JS, Paxton AM, Lister TA. Plasma cell leukemia (PCL): A report on 15 patients. Blood 1978; 52:839-45.

13. Podduturi V, Mohmand H, Gill J, Zhou XJ. Plasma cell leukemia presenting as acute kidney injury with heavy proteinuria. World J Nephrol Urol 2014; 3:129-33. doi: 10.14740/wjnu177w.

14. Rastogi P, Ahluwalia J, Parathan KK, Malhotra P. Plasma cell leukemia presenting with hyperleukocytosis and anaplasia. Indian J Hematol Blood Transfus 2017; 33:128-9. doi: 10.1007/s12288016-0740-5.

15. Heerema-McKenney A, Waldron J, Hughes S, Zhan F, Sawyer J, Barlogie B, et al. Clinical, immunophenotypic, and genetic characterization of small lymphocyte-like plasma cell myeloma: A potential mimic of mature B-cell lymphoma. Am J Clin Pathol 2010; 133:265-70. doi: 10.1309/AJCPUS3PRRT5ZXVS. 
16. Loureiro AD, Gonçalves MV, Ikoma MR, Silva MR, Colleoni GW, Chauffaille ML, et al. Plasma cell leukemia with $\mathrm{t}(11 ; 14)(\mathrm{q} 13 ; \mathrm{q} 32)$ simulating lymphoplasmacytic lymphoma: A diagnostic challenge solved by flow cytometry. Rev Bras Hematol Hemoter 2017; 39:66-9. doi: 10.1016/j.bjhh.2016.10.001.

17. Eveillard M, Moreau P. Atypical plasma cell leukemia mistaken for lymphocytosis on blood count. Blood 2015; 126:1965.

18. Noel P, Kyle RA. Plasma cell leukemia: An evaluation of response to therapy. Am J Med 1987; 83:1062-8. doi: 10.1016/0002-9343 (87)90942-9.
19. Swerdlow SH, Campo E, Harris NL, Jaffe ES, Pileri SA, Stein H, et al., Eds. WHO classification of tumours of haematopoietic and lymphoid tissues, 4th ed. From: http://publications.iarc.fr/ Book-And-Report-Series/Who-Iarc-Classification-Of-Tum ours/Who-Classification-Of-Tumours-Of-HaematopoieticAnd-Lymphoid-Tissues-2017 Accessed: Apr 2018.

20. Shtalrid M, Shvidel L, Vorst E. Polyclonal reactive peripheral blood plasmacytosis mimicking plasma cell leukemia in a patient with Staphylococcal sepsis. Leuk Lymphoma 2003; 44:379-80. doi: 10.1080/1042819021000029713.

21. Esparís-Ogando A, Alegre A, Aguado B, Mateo G, Gutiérrez N, Bladé J, et al. Bortezomib is an efficient agent in plasma cell leukemias. Int J Cancer 2005; 114:665-7. doi: 10.1002/ijc.20793. 